\title{
DEVELOPMENT OF EFFICACY ASSESSMENT PROCEDURE FOR DISASTER DEBRIS MANAGEMENT IN MUNICIPAL GOVERNMENTS IN JAPAN
}

\author{
IPPEI KAMEDA \& NAGAHISA HIRAYAMA \\ Nagoya University, Japan
}

\begin{abstract}
The objective of this study is to develop an efficacy evaluation method for disaster debris management in municipal governments in Japan. A questionnaire survey was conducted to achieve this goal. The survey used an effort assessment sheet based on Self-Assessment for Business Efforts for Disaster Prevention to assess waste management in municipal governments that are located in the promotion regions of the Nankai Trough catastrophic disaster prevention. The results of this survey indicated that the efficacy in disaster waste management will not only require planning for disaster waste, but also capacity development. Using the Incident Command System, disaster debris management by the municipal governments located in the Nankai Trough earthquake tsunami evacuation measures special enhancement area was found to be more efficient than that by other municipalities. This indicated that the experience of 2011 Tohoku disaster cultivated a sense of ownership about an impending crisis in municipal government officials through the Nankai Trough earthquake disaster prevention activities.

Keywords: disaster debris management, municipal government, efficacy, questionnaire survey, assessment procedure.
\end{abstract}

\section{INTRODUCTION}

In Japan, disaster waste management (DWM) is one of the important measures for national land resilience [1]. The Ministry of the Environment (MOE) established the guidelines for the formulation a DWM Plan [2] and implemented model projects [3] in the municipal governments. As a result, municipal governments have been promoting DWM such as formulating DWM Plan. The DWM plan is a plan in which municipal governments organize necessary items for proper, smooth, and prompt disposal of disaster waste before a disaster. And, after the disaster, municipal government will deal with DWM based on the DWM plan [2].

However, municipal governments who had drawn up the DWM Plan before the disaster was confused during the disaster [4], [5]. Therefore, it is necessary to improve the efficacy of municipal governments in DWM not only by planning DWM, but also by continuously check and review the plan already prepared.

Kimura et al. [6] surveyed 12 prefectures that created the DWM Plan after 2011 Tohoku disaster and mentioned the description rates of the items provided in the guidelines for formulating a DWM Plan in the plans prepared by each prefecture. Tajima and Osako [7] are developing a Disaster Resilience Assessment Tool for Waste Management Systems that can be used to improve the ability of municipal officials in carrying out DWM. Municipal governments can use this tool for self-assessing the disaster resilience of its waste management system. This tool uses a rating scale method for assessing items in five stages and aims to manage the progress of DWM by municipal governments. Cutter et al. [8] provided baseline indicators for recovery goals and a methodology for measuring indicators to promote the resilience of local communities. However, so far, little research has been done on methods to assess the efficacy of DWM in municipal governments. Thus, this study aimed to develop an efficacy assessment method for DWM carried out in the municipal 
governments. In addition, this method was also used to assess the efficacy of DWM in designated municipal governments in the Nankai Trough earthquake disaster prevention. In this study, the efficacy of DWM was defined as, "considering the health of residents, ensuring safety, and taking prompt action for safety and security in terms of hygiene and environment". In addition, improving the efficacy of DWM shall be based on proactive measures. And, the purpose of the Waste Management and Public Cleansing Act in Japan which is a rule before a disaster is required to be adhered to even in DWM.

\section{EXAMINATION OF EFFICACY ASSESSMENT METHOD FOR DWM}

\subsection{Self-assessment item table for business efforts for disaster prevention}

The Cabinet Office of Government of Japan published a method for Self-Assessment item table for Business Efforts for Disaster Prevention in 2007 [9]. Using this method, any company of different industry type, business format, and business scale can self-assess its own disaster prevention efforts. This table consisted of 61 items, with major categories as: I. Policy/plan, II. Concrete measures, III. Training, IV. Review, and V. Products and services that contribute to disaster prevention.

As shown in Table 1, the cell value is determined by selecting the implementation level for the target range (width) and positioning (depth) based on the implementation status of the measures of the company. Each company can self-assess their degree of achievement within a fixed level value ranging from 0 to 3 by selecting ABC and abc from "width" and "depth". Furthermore, they can also check the level distribution of achievement from the assessment result of each item and use it to examine the items to be prioritized in the next plan based on the balance of achievement levels of all items.

Table 1: Level value judgment method.

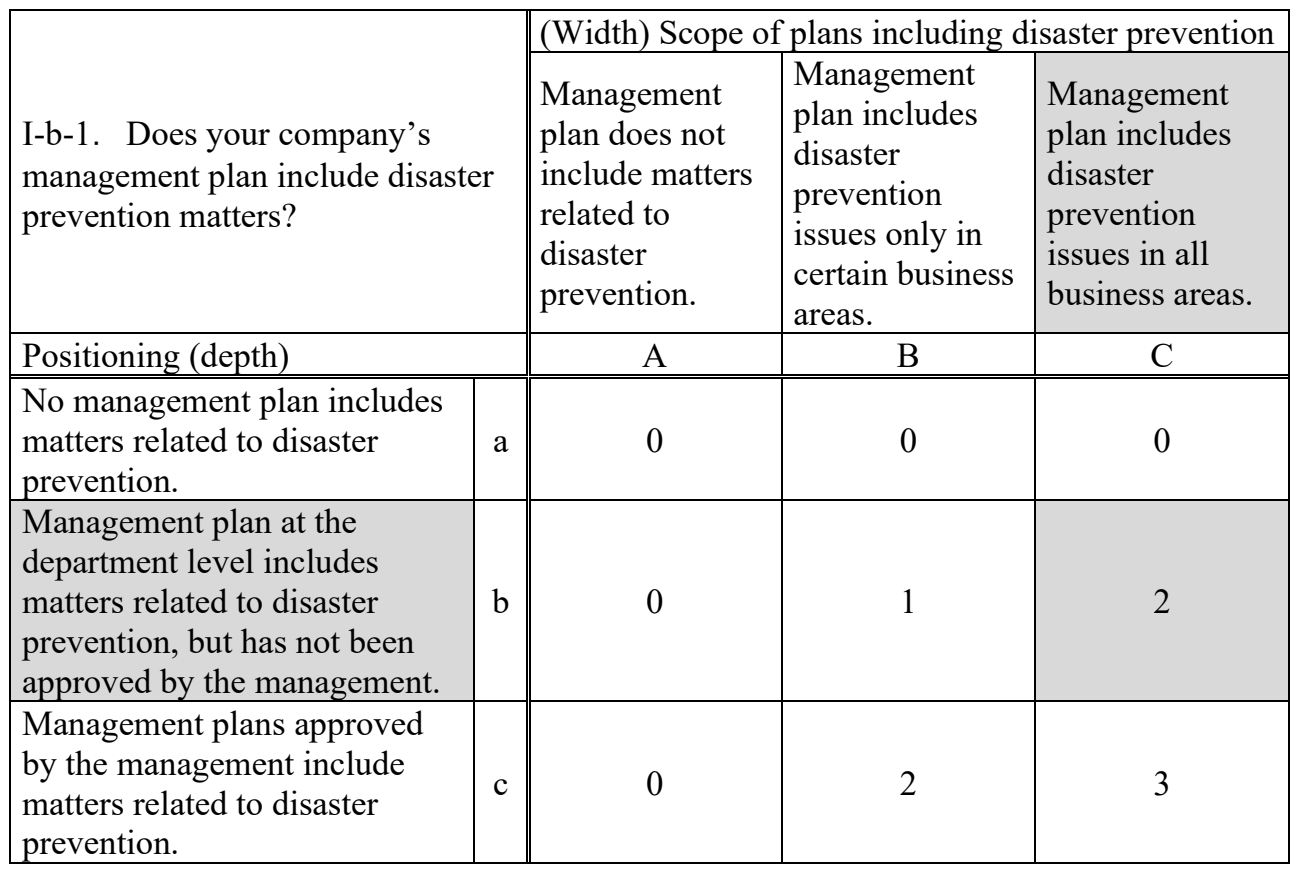


An example of the application of this method in the environmental field is the assessment carried out by Hanshin Water Supply of the enterprise association to examine the future direction of crisis management in water utilities by modifying the items in the table based on the water supply business [10].

\subsection{Efficacy assessment method for DWM}

In this study, we developed a method for assessing the efficacy of DWM by modifying the Self-Assessment item table mentioned in Section 2.1. It should be noted that the level of efficacy varied depending on the cell value set. Therefore, we considered this aspect and set a reasonable cell value, and we conducted a sensitivity analysis on that value. Furthermore, it was found that higher the level value, higher the efficacy.

\subsection{Examination of organizational functioning in DWM}

We examined the efficacy assessment of disaster waste countermeasures considering the organizational function at the time of disaster. We considered it effective to calculate the efficacy level values of each function required for DWM to comprehensively improve the DWM by the municipal governments. Tajima et al. [11] systematized the DWM carried out for the Great East Japan Earthquake using the standard crisis response system of the United States of America, Incident Command System (ICS).

Organizational functions required for DWM after a disaster are also important before the disaster. Therefore, in this study, basic functions and sub-functions required for DWM were set using ICS, as shown in Table 2.

Table 2: Basic functions and sub-functions required for DWM.

\begin{tabular}{|c|c|c|c|}
\hline Basic function & Sub-function & Basic function & Sub-function \\
\hline \multirow{3}{*}{ Command } & Goal setting & \multirow{5}{*}{ Operation } & Removal \\
\hline & Internal adjustment & & Storage \\
\hline & External affairs & & Segregation \\
\hline \multirow{2}{*}{ Public affairs } & Public relations & & Intermediate treatment \\
\hline & Human resources & & Final disposal \\
\hline \multirow{2}{*}{ Logistics } & Equipment & \multirow{5}{*}{ Planning } & Making plan \\
\hline & Plant & & Collecting information \\
\hline \multirow{3}{*}{$\begin{array}{l}\text { Finance/ } \\
\text { administration }\end{array}$} & Finance & & Information analysis \\
\hline & Contract & & Sharing information \\
\hline & Payment & & Tech support \\
\hline \multicolumn{2}{|l|}{ Training } & \multicolumn{2}{|l|}{ Review } \\
\hline
\end{tabular}

\section{SUMMARY OF QUESTIONNAIRE SURVEY}

\subsection{Design of the efficacy assessment table}

The MOE of Japan mentioned that the management of disaster waste is very important for the conservation of living environment at the time of disaster, and management requires prompt and appropriate initial response based on prior preparations by municipal governments subject of the management [12]. In addition, it has been pointed out that the turmoil immediately after the disaster delays the recovery due to prolonged treatment of 
disaster waste and increasing treatment costs [13] and significantly impedes subsequent DWM [12]. Therefore, in this study, we focused on the measures to be taken immediately after the disaster.

In this paper, we explain the efficacy assessment table prepared by us based on the selfassessment item table mentioned in Section 2.1.

We first deleted the classifications not applicable to municipal governments from the selfassessment item table, such as "products and services that contribute to disaster prevention" from the major category, and "mutual assistance/mutual assistance with other companies" and "information disclosure/social contribution" from the middle category. Alternatively, "disposal of disaster waste, human waste, etc." was added to the middle category to assess the specific measures for DWM.

The items in "disposal of disaster waste and human waste" were created considering the DWM guidelines and contents of disaster response records issued by the municipal governments and related organizations. As this study focused on measures taken immediately after the disaster, mainly, the "guidance of administrative work in DWM for municipal government" [13], that describes the minimum actions to be taken within 48 hours of the disaster, was referred. Moreover, the deleted items related to information disclosure in "information disclosure/social contribution" were added to this category.

Furthermore, we added "study on cooperation with volunteers" to "Information transmission at the time of disaster, cooperation and coordination with related organizations" and "preparation for business order, business management, etc. for DWM business after disaster" to "Backup and restoration of business facilities and securing financial resources". As a result, the number of items in the efficacy assessment table was 58. We also revised the self-assessment item table to make "width" and "depth" options in each item applicable to DWM. In addition, we interviewed four municipal officials, from different municipal governments with experience in supporting disaster area, on the efficacy assessment table. Table 3 shows the efficacy assessment table.

\subsection{Summary of questionnaire survey}

A questionnaire survey was carried out with 622 municipal governments in the area of Nankai Trough earthquake disaster prevention, excluding municipal governments in prefectures where a typhoon caused severe damages before the survey. The municipal governments in the region had set specific goals for the planning rate of DWM Plan $(60 \%)$ and time period for achieving them (by 2025) using the basic plan for Nankai Trough earthquake disaster prevention based on the Act on Special Measures for Promotion of Tohnankai and Nankai Earthquake Disaster Management [14]. The municipal governments were in the process of formulating the DWM Plan. The rate of formulating the plan by the municipal governments in Nankai Trough earthquake disaster prevention was $44 \%$ at the end of 2018 , higher than the national average of $28 \%$ [15]. Therefore, it can be said that the target area in this study was actively engaged in DWM.

In this survey, we mailed the efficacy assessment table to the department in charge of each municipal government on 25 November 2019 and asked them to respond through fax or email by 20 December 2019 .

\subsection{Questionnaire survey results}

Out of 622 municipal governments, 209 responded to the questionnaire and we mention below the status of formulation of DWM Plans by these governments. Survey results 
Table 3: Structure of efficacy assessment table and question items.

I. Policy/plan

I-a Policy

Municipal comprehensive plan and regional disaster prevention plan include matters related to DWM

I-b Plan

Have a DWM plan

Measures and implementation of training for safety confirmation are clearly stated in the plan

Measures and training for Secondary disaster prevention are described in the plan

Impact of expected disasters is assessed on waste treatment

At the time of disaster, select priority business for continuity and set its target recovery time

DWM Plan envisions multiple disaster scenarios

The plan describes measures and training for emergency recovery in case of facility damage

Measures and training for initial actions and receiving outside support are described in the plan

Discuss with related organizations on disaster coordination before disaster

I-c Organizational structure and command system

Personnel with necessary knowledge are secured through experience and training

Command system at the time of disaster is clearly defined

Contact means are secured in the event of a disaster

Command system for nighttime and holidays is in place

II. Concrete measures

II-a Ensuring life safety and safety confirmation

Procedures for ensuring the safety of executives, staff, and local residents and evacuation methods/routes for emergencies are clear

Emergency contact network and safety confirmation system are in place

A response system to prevent secondary disasters is in place

Storing daily necessities (water, emergency food, and daily necessities) after the disaster

Implementing measures to confirm the safety of executives and their families

Implementing measures to return home of employees after a disaster

II-b Reducing facility damage

Implementing earthquake countermeasures (seismic retrofitting) for major facilities

Implementing storm and flood damage countermeasures for major facilities

Implementing earthquake countermeasures for facilities and equipment

II-c Backup and restoration of business facilities and securing financial resources

Securing a backup office in case of failure of the government office

Implementing backup measures for core business systems of major facilities

Implementing measures for equipment's duplexing (private power generators, etc.)

Preparing financial resources (subsidies, supplementary budget, insurance, etc.) for disasters

Preparing for ordering and business management of DWM

Taking measures (copying etc.) to protect for important documents

II-d Information transmission at the time of disaster, cooperation and coordination with related organizations

Information collection and sharing procedures at the time of disaster are clear

Means of transmitting information to residents, related organizations, and media at the time of disaster are clear

Implementing secondary disaster prevention measures to surrounding areas in non-disaster period

Signing of agreements with local governments and related organizations

Considering collaboration with volunteers 
Table 3: Continued.

\begin{tabular}{|l|}
\hline II-e Disposal of disaster waste and human waste \\
\begin{tabular}{|l|}
\hline Actively disclosing information on DWM \\
\hline Enlightenment and public information for citizens \\
\hline Considering selection and securing of temporary storage site \\
\hline Considering management and operation of temporary storage site \\
\hline Considering disaster waste processing flow \\
\hline Considering hazardous waste and difficult-to-process waste \\
\hline Considering the installation of temporary toilets \\
\hline $\begin{array}{l}\text { Considering household waste, evacuation center waste, and human waste at the time of } \\
\text { disaster }\end{array}$ \\
\hline Considering living environment conservation \\
\hline Considering progress management of DWM \\
\hline Considering environmental measures and monitoring \\
\hline III. Training \\
\hline Training for emergency contact \\
\hline Training on mobilization/gathering \\
\hline Training on prevention of secondary disasters \\
\hline Training on restoration of facilities (equipment/systems) \\
\hline Training on business continuity based on DWM Plan \\
\hline Conducting seminars and training for DWM \\
\hline Conducting exercises and training for DWM \\
\hline Implementation of disaster prevention measures and guidance at home \\
\hline IV. Review \\
\hline Regular inspection and review of the contents of the plans \\
\hline Regular inspection and review of the operation status of the plans \\
\hline Regular inspection and review of education and training of DWM \\
\hline Regular review of executive officers on their efforts towards DWM \\
\hline Third-party diagnosis/audit system \\
\hline
\end{tabular}
\end{tabular}

indicated that the planning rate was $72.7 \%$ (152 out of 209 municipal governments) and $93.0 \%$ (40 out of 43 municipal governments) in the Nankai Trough earthquake tsunami evacuation area located in the Nankai Trough earthquake disaster prevention. Survey results also indicated that many responding municipal governments were formulating DWM Plan and actively working on DWM in the Nankai Trough earthquake tsunami evacuation area.

\section{EXAMINATION OF EFFICACY ASSESSMENT METHOD BASED ON QUESTIONNAIRE SURVEY}

\subsection{Level values in the efficacy assessment table}

The cell value in the efficacy assessment table prepared in this study was symmetrically set with respect to diagonal, with the minimum and maximum cell value scores of 0 and 3 , respectively, similar to that of the Self-Assessment item table for Business Efforts for Disaster Prevention.

Table 4 shows six combinations of cell values for sensitivity analysis. Using, for example, eqn (1), we calculated the average difference between the raw scores of efficacy level values 
for each case and case 1 in question $\mathrm{k}$. As a result, the average for 58 solutions was found to be 0.17 . Therefore, it can be concluded that the efficacy level value according to the efficacy assessment table was robust. Thus, in this study, we adopted case 1, which was the standard cell value in the matrix of the self-assessment item table

$$
\frac{1}{5} \sum_{n=2}^{6} \frac{1}{58} \sum_{k=1}^{58}(\text { raw efficacy value }(n, k)-\text { raw efficacy value }(1, k))
$$

Table 4: Examination case in the sensitivity analysis.

\begin{tabular}{|l||c|c|c|c|c|c|}
\hline & $\mathrm{A} \times 1$ & $\begin{array}{c}\mathrm{A} \times 2 \\
(\mathrm{~B} \times 1)\end{array}$ & $\begin{array}{c}\mathrm{A} \times 3 \\
(\mathrm{C} \times 1)\end{array}$ & $\mathrm{B} \times 2$ & $\begin{array}{c}\mathrm{B} \times 3 \\
(\mathrm{C} \times 2)\end{array}$ & $\mathrm{C} \times 3$ \\
\hline \hline Case1 & 0 & 0 & 0 & 1 & 2 & 3 \\
\hline Case2 & 0 & 0 & 1 & 1 & 2 & 3 \\
\hline Case3 & 0 & 0 & 1 & 2 & 2 & 3 \\
\hline Case4 & 0 & 1 & 1 & 1 & 2 & 3 \\
\hline Case5 & 0 & 1 & 1 & 2 & 2 & 3 \\
\hline Case6 & 0 & 1 & 2 & 2 & 2 & 3 \\
\hline
\end{tabular}

The average efficacy level value of the 209 municipal governments was calculated and was found to be relatively high in "policy/plan", as shown in Fig. 1. This was because many municipal governments had already formulated the DWM Plan. Alternatively, in "review", the efficacy level values were found to be relatively low. Thus, to ensure the efficacy of DWM Plan, it was considered necessary to inspect and review the plan [13] and maintain and improve the "policy/plan" level values in future. We consider it necessary to improve the efficacy level value of "review". As inspection and reviewing the plan is essential to ensure its efficacy, it was considered necessary to improve the level of "review" in the next. This leads to maintenance and improvement of the level values of "policy/plan".

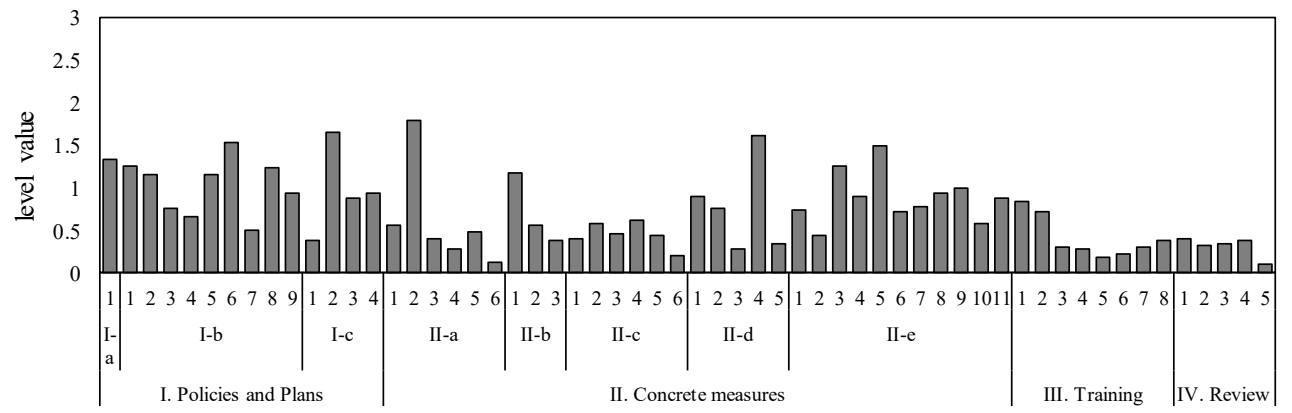

Figure 1: Raw level values of the efficacy.

Alternatively, the level values were found to be low for the items related to facilities and equipment, such as "reduction of facility damage" and "backup and restoration of business facilities and securing financial resources", except for earthquake countermeasures at major facilities. This indicated that promoting hardware measures to execute the DWM Plan is necessary. From human perspective, in "training", the efficacy level values for questions 
concerning DWM, such as facility restoration related to waste departments and training based on DWM Plan, were lower than those related to disaster prevention, such as mobilization/gathering and emergency contact. Also, in "organizational structure and command system", the level value was low in the item of "personnel with necessary knowledge are secured through experience and training". Therefore, developing human resource for DWM in future is necessary.

In "ensuring life safety and safety confirmation" under "concrete measures", while the efficacy level value of the items in the emergency contact network was high, the level of the items related to evacuation method at the time of disaster, stockpiling of daily necessities, confirmation of safety of the municipal officials' families, and measures taken for those who have difficulty returning home was low. Therefore, studying DWM considering and planning business continuity is necessary.

We next describe the classification of "information transmission at the time of disaster, cooperation, and coordination with related organizations" and "disposal of disaster waste and human waste". In this classification, the level values of the items related to following were high: agreements with related organizations, information gathering, and sharing procedures at the time of disaster; means of transmitting information to residents and disaster waste response; and specific disaster waste measures and human waste measures. First, it was considered that the high level of agreement was because the provision or placement of waste/human waste disposal service was stipulated by the Agreement by the Governor's Association of Japan [16] and that the prefecture had recently signed a comprehensive agreement at the time of disaster with the Industrial Waste Association of prefecture. Next, it was considered that the high level for the items related to DWM and human waste treatment was because $72.7 \%$ municipal governments that responded to the survey had already prepared the plan.

Finally, it was considered that the high level for the items related to information collection, information sharing procedures, and means of transmitting information to residents at the time of disaster was because these items were considered during the formulation of the plan. Alternatively, in this classification, the level of questions related to public awareness and public relations during non-disaster period and cooperation with volunteers was low. Therefore, it can be said that voluntary public relations, such as risk communication with residents, cooperation with the social welfare council, and public relations with citizens, should be strengthened during non-disaster period.

\subsection{Efficacy analysis results using ICS functions}

The 58 question items from the efficacy assessment table were categorized according to ICS functional items, as shown in Table 2, and the average efficacy level value was calculated for each function. While classifying into each function, the content of the question as well as the options were considered. When one question item was applied to multiple sub-functions, it was classified into the two most applicable items. In addition, the question concerning "operation" in the efficacy assessment table referred to multiple sub-functions (removal, storage, sorting, intermediate processing, and final disposal). Thus, sub-functions were not classified, but basic functions were classified as "operation". The main assessment target of this method was municipal governments responsible for the disposal of disaster waste. Therefore, we excluded "tech support" required by countries, prefectures, and experts from the classification. In addition, as there was no question corresponding to the sub-function "payment" in the assessment table, and it was excluded from the classification. 
Thus, the efficacy of DWM in the municipal governments was assessed based on eight categories of "command", "public affairs", "logistics", "finance/administration", "operation", "planning", "training", and "review". Fig. 2 shows the assessment results of the efficacy of DWM based on the average level values for municipal governments who responded to the survey in this study.

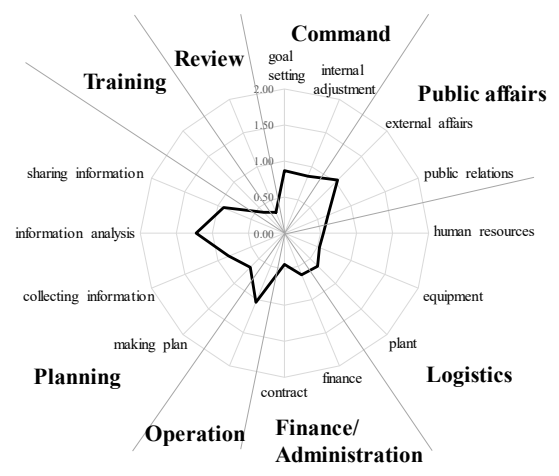

Figure 2: Assessment of ICS functional efficacy of municipal governments.

In addition, Fig. 2 shows that the efficacy of "operation" was high, while "training", "review", and "finance/administration" were low. Thus, as many municipal governments had already established a DWM Plan, it was considered that they had extensively studied "operation" related to DWM. Alternatively, due to the nature of the plan for disaster countermeasures, verifying the usefulness and validity of the plan for "review" before a disaster was difficult and it was inferred that "review" of the plan was not conducted.

The guidelines of the MOE indicate the importance of checking and reviewing the DWM Plan and mandate municipal governments to predetermine the frequency and method of checking its plans. However, the guidelines do not specifically show the frequency and method of review [2]. Based on the above, we consider that the MOE should provide concrete methods and examples for reviewing the plan. It was speculated that the low level of "training" was because of the following reason: as of 2017, the implementation rate of education and training for DWM in the municipal governments was 10\% [17], and the efforts made by municipal governments were not improving. The Fundamental Plan for National Resilience by the Cabinet Office requires the municipal governments to promote the formulation of DWM Plan and develop human resources through education and training to improve their efficacy [17]. In addition, it can be said that many municipal governments did not adequately consider procuring funds and contracts of "general finance". In addition, the Chubu Regional Environment Office of the MOE categorized the items in the DWM Plan of the municipal government in the Chubu block of Japan by dividing them into items before and after the disaster [18]. Kimura et al. [6] investigated the matters to be described in the guidelines prepared by the MOE and the Japan Society of Material Cycles and Waste Management Research, and they arranged them to be described in the DWM Plan. Of these items, those related to "operation" were described, but items related to "finance/ Administration" were not sufficiently described. In other words, it can be said that to improve the efficacy of DWM of municipal governments, it is indispensable to specifically consider matters related to "finance/administration". As a concrete consider matters related to 
"Finance/Administration", it was considered that the municipal governments will roughly estimate the DWM cost based on their damage estimation that will be required after a disaster. In addition, after the disaster, affected municipal governments must secure DWM cost until the subsidy is paid by the government. Thus, it is important to inform the finance department in advance of the cost based on damage estimation and adjust the means to secure financial resources. Next, it can be said that it is necessary for the national government to recognize the importance of "finance/administration" and provide specific technical guidance, such as necessary coordination with the finance department and securing financial resources until subsidy issuance to municipal governments.

\subsection{Study of the attributes of municipal governments and efficacy assessment}

Fig. 3 shows the efficacy assessment results from the perspective of ICS function according to the presence/absence of a DWM Plan in Nankai Trough earthquake tsunami evacuation (Area 1) and Nankai Trough earthquake disaster prevention, excluding Area 1 (Area 2). Fig. 3 shows that the municipal governments that had already prepared a DWM Plan exhibited higher assessment results in all categories than those that had yet not prepared the plan. Therefore, it cannot be said that the efficacy assessment of the DWM does not increase unless a DWM Plan is prepared. However, regarding "training", "review", and "finance/ administration", the efficacy assessment results were low regardless of the status of the formulation of DWM Plan. This was partly because, as indicated earlier, the content of the guidelines to the municipal governments of the MOE and the opportunities for human resource development by the prefectures were not sufficiently created.

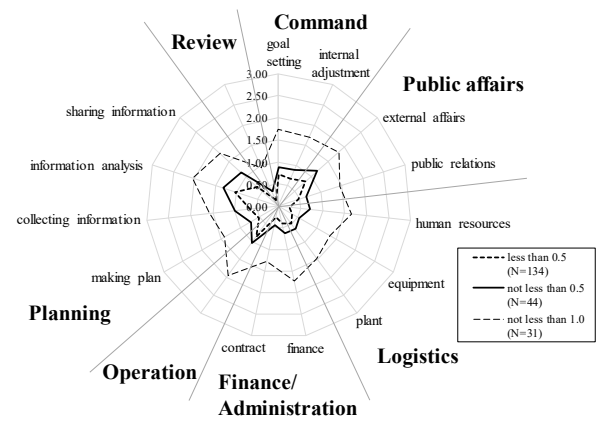

(a)

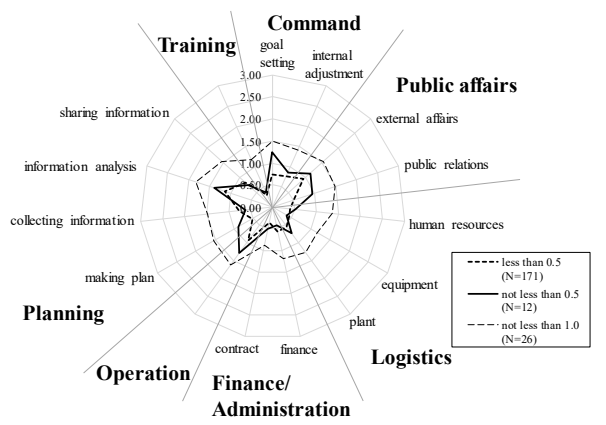

(b)

Figure 3: ICS functional efficacy assessment by attribute. (a) Plan; and (b) Area.

Fig. 3 shows that the assessment results of municipal governments of Area 1 were higher in all categories than those of Area 2. It was speculated that this was partly due the formulation of DWM Plan in the municipal governments of Area 1 being higher than that of Area 2. Tajima et al. [19] speculated that fostering a sense of ownership in municipal officials in charge would lead to continuous efforts towards DWM. Furthermore, Karatani et al. [20] found that high school students in the regions of the tsunami disaster prevention who received the tradition of tsunami damage had a higher sense of ownership than those who did not and predicted that tsunami with high waves would come from the port in their towns. This indicated that the experience of 2011 Tohoku disaster would cultivate a sense of ownership 
in the municipal government officials about the impending crisis through the Nankai Trough earthquake disaster prevention activities.

Fig. 4 shows the efficacy assessment results of the ICS category based on the results of "training" and "review" of the DWM Plan. It can be seen that the efficacy of DWM was high as the assessment results were high, 1.0 or higher in "training", for municipal governments in all categories. In particular, in the items of "human resources", "contracts", and "operation", the efficacy assessment significantly increased. This indicated that "training" is indispensable to ensure the efficacy of DWM and it improves the responsiveness of practical work in the event of a disaster.

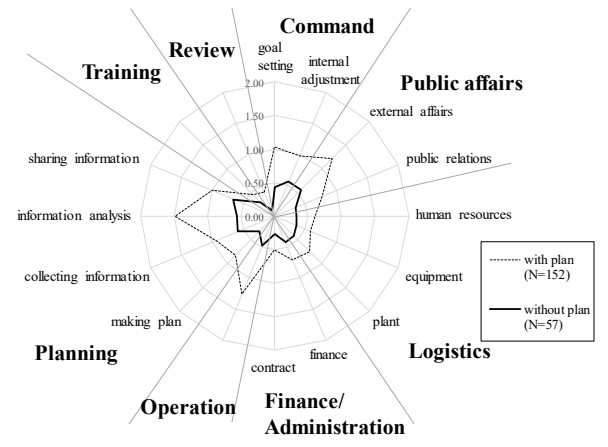

(a)

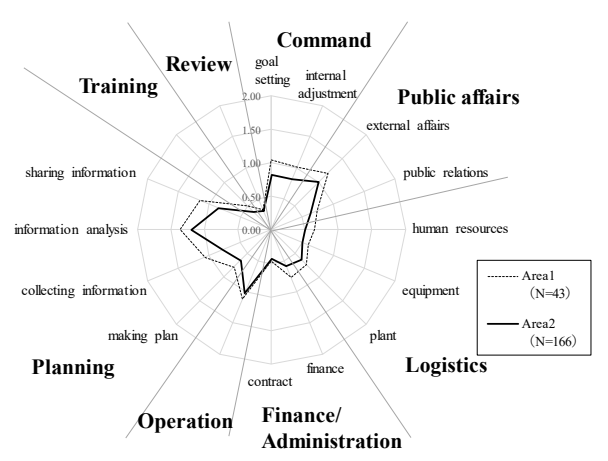

(b)

Figure 4: ICS functional efficacy assessment by (a) Training; and (b) Review.

Moreover, it can be seen that as the assessment of "review" increased, the efficacy assessment for all categories improved. However, the efficacy assessment of contracts in "finance/administration" was low, regardless of the assessment result of "review". The bill to revise a part of Waste Management and Public Cleansing Act stipulates certain measures [21], such as simplifying procedures for rapid construction of waste treatment facility and utilizing the waste treatment facilities in the event of a disaster, and alternate processing of disaster waste. However, to improve the efficacy of DWM by municipal governments, it is important to concentrate on activities, such as contracts and procedures at the time of disaster or disaster assessment work.

Thus, we developed and used the method to assess the efficacy of DWM carried out by municipal governments using eight categories: "command", "public affairs", "logistics", "finance/administration", "operation", "planning", "training", and "review". Results indicated that measures and strategies necessary for improving the efficacy of DWM can be clarified at each municipal government. Alternatively, some uncertainties existed in the quality assessment of the described contents because many choices provided for each question of in this efficacy assessment table were provided based on options, such as implementation of measures and presence/absence of description in the plan. Therefore, this table should be customized based on the implementation status of the measures and financial status of the municipal governments who use it for self-assessment. In future, it is necessary to verify the efficacy assessment method before and after disaster response and clarify the relationship between DWM and efficacy assessment. 


\section{CONCLUSIONS}

In this study, we examined the assessment method for the efficacy of disaster waste management (DWM) carried out by the municipal governments by conducting a questionnaire survey in the area of the Nankai Trough earthquake disaster prevention. The findings of the study are described below.

1. Based on the Self-Assessment item table for Business Efforts for Disaster Prevention, an assessment table for the efficacy of DWM in the municipal governments was constructed. We also developed an assessment method using eight categories: "command", "public affairs", "logistics", "finance/administration", "operation", "planning", "training" and "review"

2. It was found that the municipal governments that responded to the survey had extensively studied the "operation" related to DWM. In addition, results also indicated that to ensure the efficacy of DWM, formulation as well as "review" of the DWM Plan and "training" are essential.

3. It was also found that to improve the efficacy of DWM of the municipal governments in Japan, conducting "training" and specifically examining matters related to "finance/ administration" is necessary.

4. It was found that the efficacy assessment method for DWM can clarify the measures and strategies necessary for municipal governments to improve their efficacy.

\section{ACKNOWLEDGEMENTS}

I want to thank the municipal officials who cooperated in the questionnaire survey conducted for this study. In addition, I would like to express my gratitude towards the experienced practitioners in disaster response and support who assisted in the design of the survey.

\section{REFERENCES}

[1] Cabinet Secretariat Government of Japan, The Fundamental Plan for National Resilience, 2018.

[2] Ministry of the Environment Government of Japan, Disaster Waste Management Guideline (revised edition), 2018.

[3] Ministry of the Environment Government of Japan, Disaster waste management information website. http://kouikishori.env.go.jp/strengthening_measures/municipal_ measures/. Accessed on: 7 Jun. 2020.

[4] Ministry of the Environment Government of Japan, How local governments prepare for disposal of disaster waste generated by a giant disaster: What to learn from the case of the Great East Japan Earthquake, 2015.

[5] Kumamoto Prefecture, 2016 Kumamoto earthquake disaster record magazine in Kumamoto city: Toward recovery/reconstruction -1 year record from the disaster, 2018.

[6] Kimura, K., Nakayama, H. \& Shimaoka, T., A study on evaluation by the formulation rate for each item in disaster waste management plan in municipalities. 27th Annual Conference of JSMCWM Lecture manuscript 2016, pp. 149-150, 2016.

[7] Tajima, R. \& Osako, M., Development of disaster resilience assessment tool for waste management system. 28th Annual Conference of JSMCWM Lecture manuscript 2017, pp. 143-144, 2017.

[8] Cutter, S.L., Burton, C.G. \& Emrich, C.T., Disaster resilience indicators for benchmarking baseline conditions. Journal of Homeland Security and Emergency Management, 7(1), pp. 1-22, 2010. 
[9] Cabinet Office Government of Japan, Self-Assessment item table for "Business Efforts for Disaster Prevention", 2nd ed., 2007.

[10] Hanshin Water Supply, Crisis management measures evaluation and examination support outsourcing report, 2016.

[11] Tajima, R., Hirayama, N. \& Osako, M., Identifying emergency support functions for disaster waste management: Structuring the practical tasks undertaken in the case of Great East Japan Earthquake. J. JSNDS, 33, pp. 153-163, 2014.

[12] Ministry of the Environment Government of Japan, Basics of disaster waste management: Learning from past lessons, 2016.

[13] Ministry of the Environment Government of Japan, Guidance of administrative work in disaster waste management for municipal government, 2017.

[14] Cabinet Office Government of Japan, Basic plan for Nankai Trough earthquake disaster prevention, 2019.

[15] Ministry of the Environment Government of Japan, Disaster waste management information website. http://kouikishori.env.go.jp/action/investigative_commission/ h30_fiscal_year/pdf/document_h3103_04.pdf. Accessed on:7 Jun. 2020.

[16] The Governor's Association of Japan, Agreement on wide-area support in case of disaster in prefectures nationwide, 2016.

[17] Cabinet Office Government of Japan, National Resilience Annual Plan 2019, 2019.

[18] The Chubu Regional Environment Office of Ministry of the Environment Government of Japan, Survey and investigation work report on wide-area disaster waste management in the Chubu block at the time of a large-scale disaster in 2018, 2019.

[19] Tajima, R., Hirayama, N., Mori, T., Kawabata, T., Takata, M. \& Osako, M., Effectiveness of workshop training method on development of intentions and attitudes towards disaster waste management preparedness action. J. JSNDS, 34, pp. 99-110, 2015.

[20] Karatani, Y., Koshimura, S. \& Shuto, N., Study on systematization of disaster prevention knowledge for sustainable disaster prevention education in tsunami stricken area. Proceedings of Coastal Engineering, 50, pp. 1331-1335, 2003.

[21] Ministry of the Environment Government of Japan, Outline of the bill to revise a part of Waste Management and Public Cleansing Act, 2015. 